\title{
Pressureless sintering of silicon nitride/boron nitride laminate composites
}

\author{
E. B. PICKENS, R. W. TRICE
}

Purdue University, School of Materials Engineering, West Lafayette, Indiana 47907-2044, USA

Silicon nitride $\left(\mathrm{Si}_{3} \mathrm{~N}_{4}\right)$ and boron nitride $(\mathrm{BN})$ are materials commonly used in the production of layered ceramics [1-3] and their derivatives [4]. In composites made from these two materials, the $\mathrm{Si}_{3} \mathrm{~N}_{4}$ provides strength and the BN deflects cracks that intersect its basal planes at right angles [5]. The process of crack deflection greatly increases the length of the crack path through the sample, resulting in greater energy absorption as compared to the relatively straight crack path often observed in a monolithic ceramic.

Composites made from these materials are densified by hot-pressing because of the reluctance of BN to sinter $[2,4]$; For example, $h$-BN similar to that used in this study was hot-pressed for $1.5 \mathrm{hrs}$ at $1740^{\circ} \mathrm{C}$ under $25 \mathrm{MPa}$ with no apparent sintering observed between $\mathrm{BN}$ particles [6]. It is the strong covalent bonds on the basal planes that make for an unreactive, non-wetting compound which severely hampers the densification of $\mathrm{BN}$. Previous research on $\mathrm{Si}_{3} \mathrm{~N}_{4} / \mathrm{BN}$ composites has shown that during the hot-pressing step, the liquid phase formed in the $\mathrm{Si}_{3} \mathrm{~N}_{4}$ cells is forced into the $\mathrm{BN}$ cell boundaries [5]. This glassy phase, which has a composition that is a function of the sintering aids used and the silica on the surface of the silicon nitride, acts as a "glue" to hold the BN platelets together. It is proposed that if the sintering aids are added in the appropriate proportion directly to the $\mathrm{BN}$ powder [7], as well as to the $\mathrm{Si}_{3} \mathrm{~N}_{4}$ [8-15], laminate composites may be densified by pressureless sintering.

$\alpha$-silicon nitride (UBE Industries E-10, $\sim 0.5 \mu \mathrm{m}$ diameter) was ball milled with $4 \mathrm{wt} \% \mathrm{Al}_{2} \mathrm{O}_{3}$ (Alcoa A$16 \mathrm{SG}, \sim 0.4 \mu \mathrm{m}$ in diameter) and $4 \mathrm{wt} \% \mathrm{Y}_{2} \mathrm{O}_{3}$ (Alfa Aesar REacton, $\sim 10 \mu \mathrm{m}$ in diameter) to create the silicon nitride layers (presently identified as $\mathrm{Si}_{3} \mathrm{~N}_{4}-4 \mathrm{~A} 4 \mathrm{Y}$ ). From prior work [16], the $\mathrm{Si}_{3} \mathrm{~N}_{4}-4 \mathrm{~A} 4 \mathrm{Y}$ composition investigated for the $\mathrm{Si}_{3} \mathrm{~N}_{4}$ was determined to sinter to $92.3 \%$ and be composed of entirely $\beta-\mathrm{Si}_{3} \mathrm{~N}_{4}$. The $\mathrm{BN}$ layer was made with $h$-BN (Advanced Ceramics HCP) to which $34.3 \mathrm{wt} \%$ each of alumina and yttria powders, $17.1 \mathrm{wt} \% \alpha-\mathrm{Si}_{3} \mathrm{~N}_{4}$ and $2 \mathrm{wt} \% \mathrm{SiO}_{2}$ (Alfa Aesar REacton, $<45 \mu \mathrm{m}$ ) were also added. Prior work showed this composition to sinter to $66 \%$ of its theoretical density [16]. This composition of $\mathrm{BN}$ powders will be referred to as $88 \mathrm{BN}$ in the rest of the text. The powders that were used to form the $\mathrm{Si}_{3} \mathrm{~N}_{4}-4 \mathrm{~A} 4 \mathrm{Y}$ and $88 \mathrm{BN}$ layers were ball-milled in methanol for $1 \mathrm{hr}$ using zirconia milling media prior to assembling the layered ceramic.

The compact was fabricated by adding alternating layers of $2 \mathrm{~g}$ of $\mathrm{Si}_{3} \mathrm{~N}_{4}-4 \mathrm{~A} 4 \mathrm{Y}$ powder, followed by a
$0.9 \mathrm{~g}$ layer of $88 \mathrm{BN}$ powder, to a steel die with inner dimensions of $76 \mathrm{~mm} \times 38 \mathrm{~mm} \times 6 \mathrm{~mm}$. Note that a total of 15 layers were stacked, with the top and bottom layers composed of $\mathrm{Si}_{3} \mathrm{~N}_{4}-4 \mathrm{~A} 4 \mathrm{Y}$. In addition, the $88 \mathrm{BN}$ powder intentionally did not completely cover the $76 \mathrm{~mm} \times 38 \mathrm{~mm}$ area; rather, the perimeter was kept free of the $88 \mathrm{BN}$ powder so that adjacent layers of $\mathrm{Si}_{3} \mathrm{~N}_{4}-4 \mathrm{~A} 4 \mathrm{Y}$ would touch. The thickness of the perimeter was $\sim 3 \mathrm{~mm}$. It is thought that sintering of the $\mathrm{Si}_{3} \mathrm{~N}_{4}-4 \mathrm{~A} 4 \mathrm{Y}$ powder would provide an additional compaction force to the 88BN layers. After all the layers were added, the composite was pressed in a laboratory press at $\sim 7 \mathrm{MPa}$. The compact was removed from the die and packed in a powder bed consisting of $60 \mathrm{wt} \% \alpha-\mathrm{Si}_{3} \mathrm{~N}_{4}$ and $40 \mathrm{wt} \% \mathrm{BN}$, and sintered in a $\mathrm{BN}$ crucible at $1800^{\circ} \mathrm{C}$ for $3 \mathrm{hrs}$ in flowing nitrogen gas in a Centorr Testorr furnace. In addition to the layered ceramic, individual compacts of $\mathrm{Si}_{3} \mathrm{~N}_{4}-4 \mathrm{~A} 4 \mathrm{Y}$ powder and the $88 \mathrm{BN}$ powder were pressed and sintered similarly to the layered ceramic. Table I presents the properties of these monolithic ceramics [17]; these properties were used to predict the expected mechanical properties of the layered ceramic.

The average density of three 15-layered test specimens was $\sim 2.1 \mathrm{~g} / \mathrm{cm}^{3}$, approximately $66 \%$ of its theoretical density of $\sim 3.4 \mathrm{~g} / \mathrm{cm}^{3}$. The theoretical density (TD) was calculated based on the composite having $\sim 65 \mathrm{vol} \% \mathrm{Si}_{3} \mathrm{~N}_{4}-4 \mathrm{~A} 4 \mathrm{Y}\left(\mathrm{TD} \sim 3.26 \mathrm{~g} / \mathrm{cm}^{3}\right.$ ) and $\sim 35$ vol\% 88BN (TD $\sim 3.66 \mathrm{~g} / \mathrm{cm}^{3}$ ), as determined from point-count analysis. X-ray diffraction of the faces parallel to the pressing direction, using $\mathrm{Cu} \mathrm{K}_{\alpha}$ radiation, revealed only $\beta-\mathrm{Si}_{3} \mathrm{~N}_{4}$ and $h$-BN peaks.

Standard 4 pt. bend mechanical test specimens [18], $3 \mathrm{~mm} \times 4 \mathrm{~mm} \times 50 \mathrm{~mm}$, were machined from the $\mathrm{Si}_{3} \mathrm{~N}_{4}-4 \mathrm{~A} 4 \mathrm{Y} / 88 \mathrm{BN}$ layered composite. The as-sintered surface was not polished prior to testing due to minor surface curvature. A fully articulated $\mathrm{SiC} 4$ pt-bend flexural fixture with inner and outer spans of 20 and $40 \mathrm{~mm}$, respectively, was used to fracture the speci-

TAB LE I Physical and mechanical properties measured for compacts of $\mathrm{Si}_{3} \mathrm{~N}_{4}-4 \mathrm{~A} 4 \mathrm{Y}$ and $88 \mathrm{BN}$ powders. Powders were sintered similarly to the layered ceramic and have been included for comparison purposes

\begin{tabular}{lllll}
\hline $\begin{array}{l}\text { Powder } \\
\text { compact }\end{array}$ & $\begin{array}{l}\text { Sintered } \\
\text { density } \\
\left(\mathrm{g} / \mathrm{cm}^{3}\right)\end{array}$ & $\begin{array}{l}\text { Total } \\
\text { porosity } \\
(\%)\end{array}$ & $\begin{array}{l}\text { Flexure } \\
\text { strength } \\
(\mathrm{MPa})\end{array}$ & $\begin{array}{l}\text { Elastic } \\
\text { modulus } \\
(\mathrm{GPa})\end{array}$ \\
\hline $\mathrm{Si}_{3} \mathrm{~N}_{4}$-4A4Y powder & 3.01 & 8 & $184 \pm 50$ & $\begin{array}{c}202 \pm 27 \\
35 \pm 2\end{array}$ \\
\hline $8 \mathrm{BN}$ powder & 2.42 & 34 & $31 \pm 1$ & $35 \pm 2$ \\
\hline
\end{tabular}




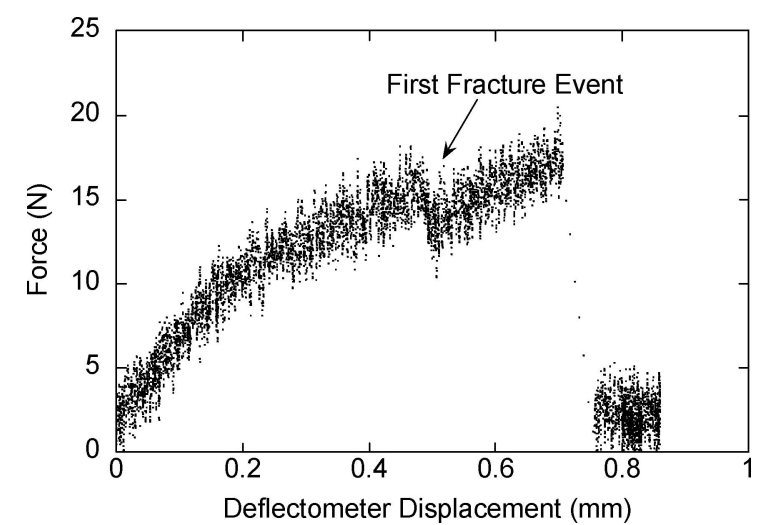

Figure 1 A representative example of the failure behavior of the $\mathrm{Si}_{3} \mathrm{~N}_{4}$ 4A4Y/88BN layered composite. Notice the "stair-step" failure which indicated crack deflection had occurred.

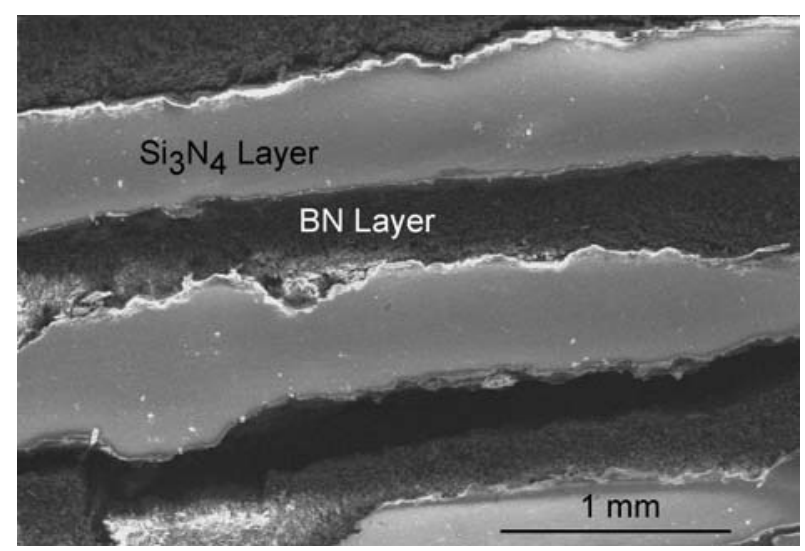

Figure 2 An SEM image of the $\mathrm{Si}_{3} \mathrm{~N}_{4}-4 \mathrm{~A} 4 \mathrm{Y} / 88 \mathrm{BN}$ layered composite. Note the varying thickness of the $\mathrm{Si}_{3} \mathrm{~N}_{4}$ and $\mathrm{BN}$ layers. (Sample was metal coated, and the microscope was operated at $25 \mathrm{keV}$.)

mens. Each specimen was tested at a displacement rate of $0.5 \mathrm{~mm} / \mathrm{min}$; deflection of the beam was measured directly by placing a deflectometer-type extensometer in the center of the tensile surface of the sample. The elastic modulus, fracture strength, and the work of frac- ture were calculated. The stiffness of the load frame and the $\mathrm{SiC}$ fixture were accounted for in the calculation of elastic modulus [19]. The work of fracture was defined as the area under the load vs. deflectometer displacement curve divided by two times the cross-sectional area of the specimen.

A representative load vs. deflectometer displacement curve for a $\mathrm{Si}_{3} \mathrm{~N}_{4}-4 \mathrm{~A} 4 \mathrm{Y} / 88 \mathrm{BN}$ layered specimen tested in flexure is shown in Fig. 1. The average modulus for the three 15-layered samples was $\sim 5 \mathrm{GPa}$. The flexural strength of two of the samples was 6 and $2 \mathrm{MPa}$. One sample failed by crushing under the load pin and was not further analyzed. The work of fracture of the two specimens was determined to be 218 and $162 \mathrm{~J} / \mathrm{m}^{2}$.

A polished cross-sectional SEM micrograph of a layered sample prior to fracture is shown in Fig. 2. It was observed that the $\mathrm{Si}_{3} \mathrm{~N}_{4}-4 \mathrm{~A} 4 \mathrm{Y}$ layers were nominally $500 \mu \mathrm{m}$, while the layers of the $88 \mathrm{BN}$ were slightly thinner. Furthermore, it is clear that the layers have a large variation in thickness along their length. Fig. 3 is a cross-sectional view of a specimen after testing. From this composite micrograph, it is clear that significant crack deflection is occurring as it was observed that cracks propagating in the $88 \mathrm{BN}$ layer were turned $90^{\circ}$ as they approached the $\mathrm{Si}_{3} \mathrm{~N}_{4}-4 \mathrm{~A} 4 \mathrm{Y}$ layer. Evidence of crack deflection is also apparent in Fig. 1, where some load bearing ability of the sample is observed after the first fracture event.

Despite evidence of crack deflection, clearly the modulus and strength values are lower than would be expected from a rule of mixtures estimate assuming isostrain conditions using properties of monolithic $\mathrm{Si}_{3} \mathrm{~N}_{4}-4 \mathrm{~A} 4 \mathrm{Y}$ and $88 \mathrm{BN}$ billets. These values are presented in Table I. For example, based on $\sim 65$ vol\% $\mathrm{Si}_{3} \mathrm{~N}_{4}-4 \mathrm{~A} 4 \mathrm{Y}$ and $\sim 35$ vol\% $88 \mathrm{BN}$, modulus and strength values of $142 \mathrm{GPa}$ and $131 \mathrm{MPa}$, respectively, would be anticipated. Furthermore, it is common to observe work of fractures of $\sim 7,000 \mathrm{~J} / \mathrm{m}^{2}$ in silicon

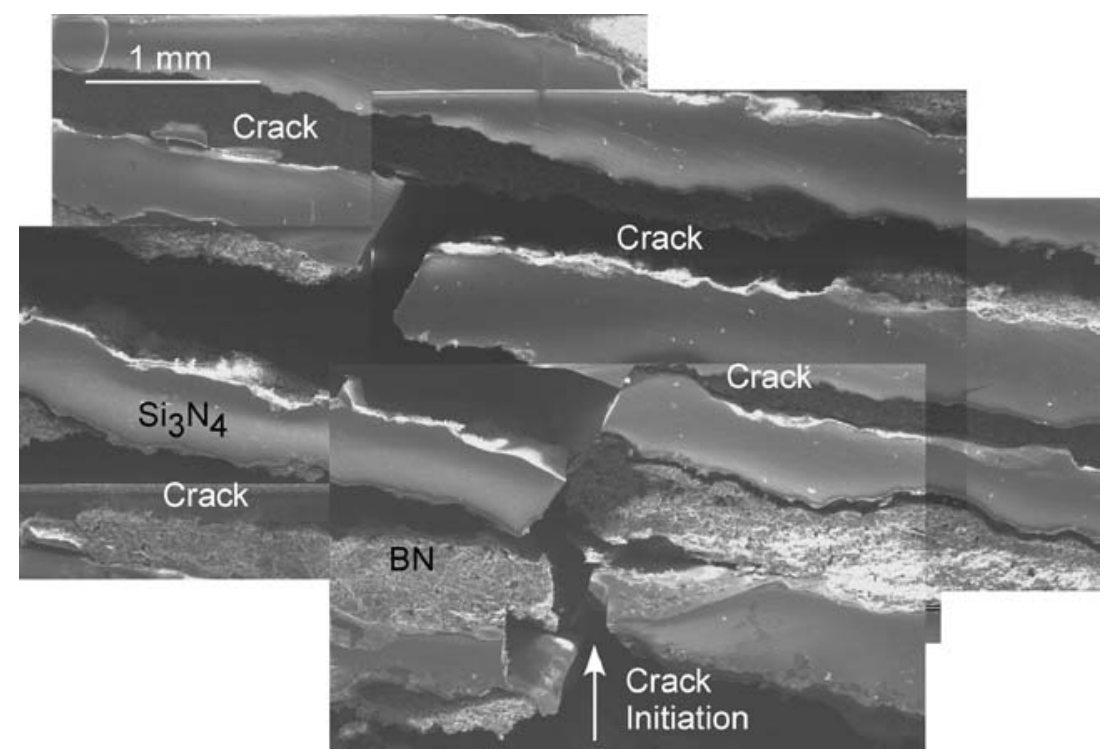

Figure 3 SEM image illustrating the crack propagation through the $\mathrm{Si}_{3} \mathrm{~N}_{4}-4 \mathrm{~A} 4 \mathrm{Y} / 88 \mathrm{BN}$ layered composite. The sample is oriented such that the tensile surface corresponds to the bottom of the micrograph. It was usually observed that crack deflection (i.e., the vertically propagating crack was turned $90^{\circ}$ down the interface) occurred as the vertically oriented crack approached the $\mathrm{Si}_{3} \mathrm{~N}_{4}-4 \mathrm{~A} 4 \mathrm{Y}$ layer. (Sample was metal coated, and the microscope was operated at $25 \mathrm{keV}$.) 
nitride/boron nitride composites [4]. One reason for these low properties is explained by considering the outer $\mathrm{Si}_{3} \mathrm{~N}_{4}-4 \mathrm{~A} 4 \mathrm{Y}$ layers; both specimens that failed in tension showed evidence of cracking in the outer layers prior to testing. Although care was taken to put these defects in compression or outside of the inner loading pins during testing, there were likely cracks that could not be visually detected. The source of these cracks was likely due to residual stresses that developed due to different shrinkage amounts associated with each material type. In the current study, the $\mathrm{Si}_{3} \mathrm{~N}_{4}-4 \mathrm{~A} 4 \mathrm{Y}$ demonstrated considerably more in-plane shrinkage than the 88BN layers.

The mechanical properties of the layered composite were also likely influenced by the local microstructure in the $\mathrm{Si}_{3} \mathrm{~N}_{4}-4 \mathrm{~A} 4 \mathrm{Y}$ and $88 \mathrm{BN}$ layers. For the $\mathrm{Si}_{3} \mathrm{~N}_{4}-$ 4A4Y layers, the uneven thickness of the coating likely resulted in significant stress concentrations that could further reduce their strength (see Fig. 2). In the 88BN layers, alignment of basal planes of $\mathrm{BN}$ perpendicular with respect to the plane of the layer would provide regions for easy crack propagation. Ultimately, the properties of these laminates could be improved by using processing techniques to better control the thickness and alignment of grains in each layer. In particular, a technique like tape casting could be used to produce the layers of $\mathrm{Si}_{3} \mathrm{~N}_{4}-4 \mathrm{~A} 4 \mathrm{Y}$ or $88 \mathrm{BN}$. For the $88 \mathrm{BN}$ layers, the flow of the plate-like $\mathrm{BN}$ grains under the blade would likely orient basal planes parallel with respect to the plane of the coating, which would increase crack deflection.

In summary, it was possible to produce a layered structure via pressureless sintering to mimic the noncatastrophic failure of hot-pressed $\mathrm{Si}_{3} \mathrm{~N}_{4}$ /BN laminate composites. Load versus deflection curves clearly showed some residual strength following the first fracture event, and crack deflection was correlated with crack deflection at the $\mathrm{Si}_{3} \mathrm{~N}_{4}-4 \mathrm{~A} 4 \mathrm{Y} / 88 \mathrm{BN}$ interface. However, the strengths of these layered composites were far less than anticipated. It is believed that by improving the processing methods the mechanical properties of this composite could be greatly improved.

\section{Acknowledgments}

The authors wish to thank a Department of Education GAANN Fellowship, grant \# P200A010403, that supported this research.

\section{References}

1. C. WANG, Y. HUANG, Q. ZAN, L. ZOU and S.CAI, J. Amer. Ceram. Soc. 85(10) (2002) 2457.

2. D. KOVAR, M. D. THOUleSS and J. W. HALLORAN, ibid. 81(4) (1998) 1004.

3. H. LIU and S. M. HSU, ibid. 79(9) (1996) 2452.

4. D. KOVAR, B. KING, R. TRICE and J. HALLORAN, ibid. 80(10) (1997) 2471.

5. R. W. TRICE and J. W. HALLORAN,ibid. 82(9) (1999) 2502.

6. RODNEY TRICE, Ph.D. Dissertation, University of Michigan, 1998.

7. R. W. TRiCE and J. W. Halloran, J. Amer. Ceram. Soc. 82(9) (1999) 2563.

8. G. R. TERWilliger and F. F. LANGe, J. Mater. Sci. 10 (1975) 1169.

9. J. T. SMith and C. L. QuAkenbush, Amer. Ceram. Soc. Bull. 59(5) (1980) 529.

10. H. F. PRIEST, G. L. PRIEST and G. E. GAZZA, J. Amer. Ceram. Soc. 60(1/2) (1977) 81.

11. R. E. LOEHMAN and D. J. ROWCLIFFE, ibid. 63(3/4) (1980) 144.

12. Y. HAITAO, L YANG, R. GAO, Y. RUNZHANG, Y. GUOTAO and H. PEIYUN, Mater. Chem. Phys. 69 (2001) 281.

13. M. PUECKERT and P. GREIL, J. Mater. Sci. 22 (1987) 3717.

14. S. HAMPS HIRE, "Nitride Ceramics," Material Science and Technology: A Comprehensive Treatment, Vol. 11, Structure and Properties of Ceramics, edited by R. W. Cahn, P. Haasen and E. Kramer (VCH Publishers, 1994) Chapt. 3, p. 119.

15. J. H. EDGAR, "Crystal Structure, Mechanical Properties, and Thermal Properties of BN," in Properties of Group III Nitrides, edited by J. H. Edgar (INSPEC, London, UK, 1994) p. 7.

16. E. PIC KENS and R. W. TRICE, Innovative Processing and Synthesis of Ceramics, Glasses, and Composites VII (Ceramic Transactions, 2003) Vol. 154, p. 123.

17. E. PICKENS, Master's Degree Document submitted to the School of Materials Engineering, Purdue University, 2003.

18. ASTM standard C1161-02c.

19. N. SUNDARAM, R. W. TRICE and K. J. BOWMAN, in "Advances in Ceramic Matrix Composites IX" (Ceramic Transactions, 2003) Vol. 153, p. 253.

Received 12 February

and accepted 10 August 2004 